\author{
О. П. ВЕНГЕР, Л. М. САС, Ю. І. МИСУЛА, О. Є. СМАШНА, В. С. БЛЛУС, О. О. ЛЮТА, \\ Т. П. ГУСЄВА, М. Є. КОВАЛЬ, В. О. ПАСТУШАК
}

\title{
МОЖЛИВОСТІ АДАПТАЦІЙНИХ РЕСУРСІВ ЕМІГРАНТІВ ТА РЕЕМІГРАНТІВ ВІДПОВІДНО ДО ЇХ ОСОБИСТІСНИХ ОСОБЛИВОСТЕЙ
}

\author{
Тернопільський національний медичний університет імені І. Я. Горбачевського МОЗ України, \\ м. Тернопіль, Україна
}

\begin{abstract}
Мета: вивчити можливості адаптаційних ресурсів емігрантів та реемігрантів відповідно до їх особистісних особливостей.

Матеріали і методи. Використано клініко-психопатологічний, психометричний (шкала депресії M. Hamilton (HDRS), шкала тривоги M. Hamilton (HARS), шкала оцінки суїцидального ризику Г. В. Старшенбаума) та психодіагностичний методи.

Результати. Вивчення структури депресивного синдрому різного етіологічного спрямування (ендогенного, екзогенного та органічного) у емігрантів та реемігрантів, а також особливостей афективних розладів, що виникають за умов міграції, $€$ не лише ключовим завданням сьогодення, а й спробою вирішення соціальних проблем. Реалізація цих завдань допоможе знайти диференційований підхід до лікування та відшукати раціональні шляхи надання допомоги.

Отримані дані доповнюють наявну інфрормацію про зміну психологічного стану мігрантів: встановлено особливості симптомів депресивного спектра, закономірності їх виникнення, ступінь вираження та можливості суїцидальної активності залежно від походження розладів. З'ясовано, що об'єктивні соціально-психологічні умови створюють підґрунтя для виникнення закономірних порушень, що разом з індивідуальними рисами особистості призводять до розвитку невротичних варіантів дезадаптації та декомпенсації особистості у бік посилення гальмівних реакцій.

Висновки. На підставі комплексного дослідження встановлено закономірності афективних розладів, що можуть слугувати основою для розробки та апробації нових підходів лікування та методів реабілітації осіб, які зазнали міграції.
\end{abstract}

КЛЮчОВІ СЛОВА: адаптаційні можливості; емігранти та реемігранти; афективні розлади; особистісні риси.

Дослідження особистісних особливостей емігрантів та реемігрантів має велике значення у виявленні та вивченні основних тенденцій зміни патопсихологічного здоров'я населення внаслідок процесу міграції [5]. Встановлені закономірності допомагають побачити причини та механізми розвитку даних порушень. На основі отриманих даних з'являються можливості віднайти шляхи попередження та купірування виявлених розладів із метою покращення адаптаційних ресурсів емігрантів [7]. Вирішення цього завдання $є$ плацдармом не лише для покращення активної життєвої позиції людей, які покинули домівки, але й розв'язання певних соціальних та національних питань, які безперечно внесла міграція в українське суспільство.

Мета дослідження: вивчити можливості адаптаційних ресурсів емігрантів та реемігрантів відповідно до їх особистісних особливостей.

Матеріали і методи. Обстежено 412 хворих, які лікувалися в КНП «Тернопільська обласна клінічна психоневрологічна лікарня» Тернопільської обласної ради з приводу афрективних розладів психогенного, ендогенного та органічного генезу. До обстежуваних входили емігранти, неемігранти та реемігранти. Дослідження включали клініко-психопатологічний метод, психометричний (шкала депресії M. Hamilton (HDRS), шкала тривоги M. Hamilton (HARS), шкала оцінки суїцидального ризику Г. В. Старшенбаума), особистісні та проективні психодіагностичні тести (стандартизований метод дослідження особистості Л. Н. Собчик [6].

Результати дослідження та їх обговорення. Депресивні розлади ендогенного та психогенного походження у емігрантів характеризувалися наявністю тривожно-депресивного та тоскного типів афектів, які переважали над апатичним і змішаним за органічного розвитку депресії. У структурі депресивного синдрому пацієнтів внаслідок психогенних та органічних розладів більшою мірою переважали інсомнічний, астенічний та соматизовані варіанти. У той час для ендогенного походження таких розладів, окрім цих порушень, характерною була наявність астенічної, вітальної та ажитованої депресії [3].

\footnotetext{
() О. П. Венгер, Л. М. Сас, Ю. І. Мисула, О. Є. Смашна, В. С. Білоус, О. О. Люта, Т. П. Гусєва, М. Є. Коваль,

В. О. Пастушак, 2020
} 
При обстеженні емігрантів із психогеніями за допомогою шкали HDRS загальний показник психогенної депресії склав $(42,5 \pm 6,0)$ бала. Причому до тяжкої депресії належали 34,5 \% пацієнтів цієї когорти, а решта - депресії середньої тяжкості. Наступний щабель відповідно до цієї шкали займала депресія органічного походження, що становила рівень тяжкої у 55 \%, в той же час показник ендогенної депресивності виявився значуще більшим, а структура тяжкості синдрому становила, відповідно, 73,0 \% - тяжка та 27,0 \% - середньої тяжкості.

Шкала HARS продемонструвала високий рівень тривоги 3 тривожним настроєм, напруженням, інсомнією, когнітивними порушеннями як у пацієнтів з психогенною, так і з депресією ендогенного походження. Причому стан пацієнтів за умов ендогенного походження знову виявився тяжчим, а відсоток хворих із тяжкою тривогою більшим і склав 54,4%. Пацієнти 3 органічною патологією продемонстрували високий рівень тривоги, ажитації, іпохондрії та дисомній.

Суїцидальні тенденції в емігрантів, хворих з психогенною депресією, виявили у більшості хворих. Хоча у цих пацієнтів були пасивні прояви суїцидальної поведінки, а низький показник суїцидального ризику склав 52,2 \%. На противагу цим даним, суїцидальна поведінка пацієнтів 3 ендогенними розладами характеризувалася високою суїцидальною дієвістю, більшою кількістю суїцидальних активностей. Структура суїцидального ризику виглядала наступним чином: високий рівень ризику - 22,4 \%, середній - 37,3\% та низький - 40,3 \%. Виражений суїцидальний ризик характерний також для емігрантів 3 органічною патологією.

При обстеженні реемігрантів встановлено значущо більше значення вітальної депресії на противагу алгічній, ажитованій депресіям та психопатологічному афректу в емігрантів.

Шкала HDRS у реемігрантів із психотичним генезом захворювання продемонструвала високі показники депресивності та менш виражені - тривоги, інсомнії, ажитації та суїцидальних намірів. У той же час психотичні явища та обсесивно-компульсивні розлади практично не спостерігали. До тяжкої депресії з цієї групи обстежених належали 48,5 \%, а до середньої тяжкості - 51,5\%.

Необхідно наголосити, що для реемігрантів характерною була наявність тривожності, причому тяжкий її варіант спостерігали в третини хворих, що нагадувало результати емігрантів 3 ендогенними порушеннями. Загалом у емігрантів, порівняно з реемігрантами, спостерігали значущо більші показники соматизації, обсесивнокомпульсивної симптоматики та тривожності, а у реемігрантів - показники депресії. При порівнянні емігрантів та реемігрантів, які страждали від депресій органічного походження, встановлено вірогідно вищу тривожність та схильність до обсесивно-компульсивних дій емігрантів, а сензитивність та схильність до депресії реемігрантів.

Для категорії психогенних депресій виявилась висока суїцидальна активність з виконаними суїцидальними спробами у пацієнтів, які склали практично $15 \%$.

Структура клінічних симптомів ендогенної депресії у реемігрантів мала свої особливості: половина пацієнтів відзначала апатичний афект, чверть тривожно-депресивний та тоскний. I в цій когорті спостерігали наявність суїцидальних думок та нездатність приймати рішення. Посиндромний поділ у даної групи виглядав таким чином: найбільшу частку склали вегетативні розлади, інсомнії та прояви вітальної депресії, що становили, відповідно, 38,4, 57,5 та 41, 5 \%. Меншою мірою відзначали апатичну депресію, ажитацію, психопатологічний та алгічний синдроми. Малохарактерними були депресивна та тривожна манія. При порівнянні реемігрантів та емігрантів з ендогенною депресією статистично значущими виявилися зміни щодо психопатологічного синдрому, депресивної та тривожної манії, ажитованої депресії.

Показники ендогенної депресії за шкалою HDRS виявилися схожими 3 показниками внаслідок психогенних впливів за рівнем депресії та її структурою, але потрібно звернути увагу на вдвічі вищий показник пацієнтів із тяжкою депресією ендогенного походження.

Таким чином, порівнюючи групи емігрантів та реемігрантів з ендогенними розладами, ми відзначили, що емігранти характеризувалися вищими показниками соматизації та тривожності, а реемігранти - міжособистісної сензитивності та депресії. У той час як показники соматизації, обсесивно-компульсивної симптоматики та тривожності значуще відрізнялися в обох групах від контролю. Щодо суїцидальної активності, то вона була притаманною реемігрантам усіх типів депресії та виявилася значуще вищою у реемігрантів порівняно з емігрантами [2].

При визначенні особистісного профрілю у всіх групах обстежуваних виявлено високі показники песимістичності, тривожності та надконтролю.

Відповідно до шкали песимістичності, що найбільш значуще демонструє депресивні розлади, типовим виявились ознаки гіпостенічного типу реагування. Найвищі показники песимістичності спостерігали у реемігрантів та емігрантів. Виявлені дані $є$ результатом впливу незвичних життєвих обставин із необхідністю напруження адаптивних можливостей, особливостями індивідуальнотипологічних рис особистості, які ускладнюють процес пристосування [1]. Зміни психоемоційного стану, зумовленого впливом об'єктивних соціально-психологічних фракторів, призвели до по- 
єднання інших профрілей поряд із домінуванням депресивного. Таким чином, найбільш демонстративним виявилося поєднання зі шкалою тривожності, індивідуалістичності та надконтролю.

Такий стан проявляється постійно зниженим фроном настрою, тривогою, помисливістю, і свідчить про акцентуацію або патохарактерологічний розвиток за гіпотимним (дистимічним) типом, схильністю до почуття провини, тривожністю, невпевненістю у собі, депресивними тенденціями [4].
Патохарактерологічні та патоперсонологічні показники (рис. 1) у групах хворих з ендогенною депресією відрізнялися більш глибокими змінами, що демонстрували песимістичність, схильність до драматизації ситуації, та наявністю почуття провини, фріксацією на негативних переживаннях порівняно з психогенними розладами. Це відображає більш глибокі депресивні переживання з вираженим вітальним компонентом у цієї категорії пацієнтів.

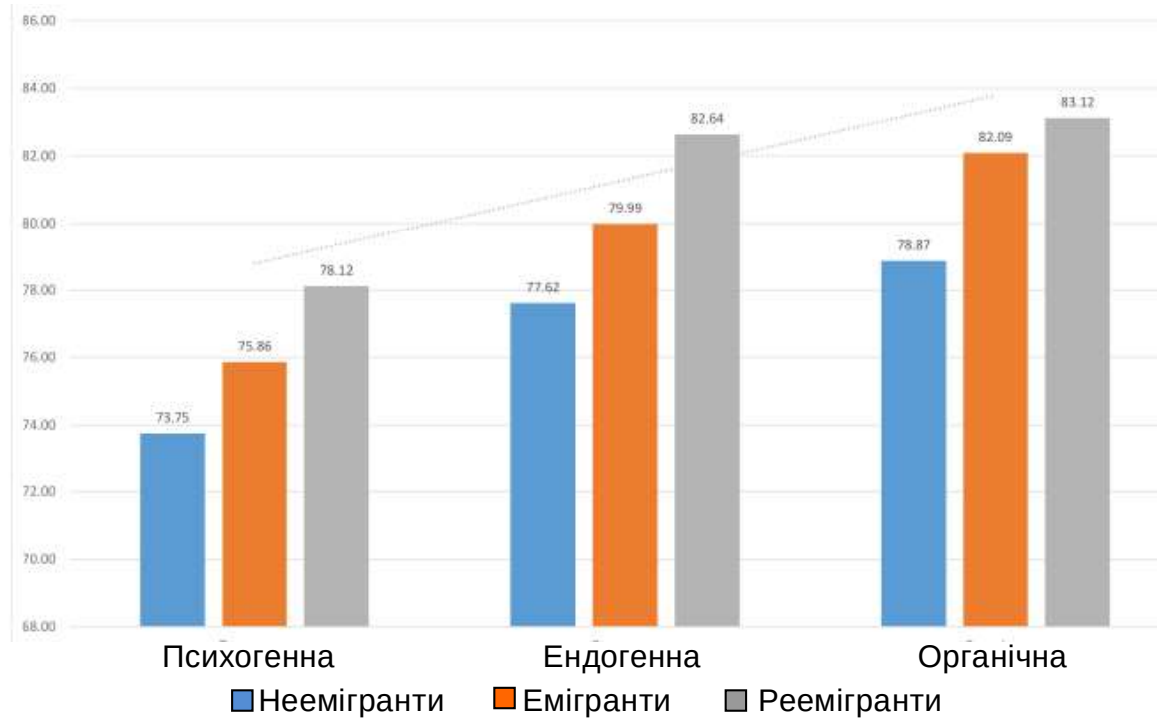

Рис. 1. Профріль песимістичності.

Натомість органічні депресивні розлади відрізнялися значною ригідністю і стабільністю проявів, на відміну від хворих на ендогенну та, особливо, психогенну депресію, характеризувалися спільними тенденціями і відрізнялися переважно кількісними значеннями показників.

Таким чином, лідером показників виявилась песимістичність, яка була найменшою у неемігрантів при психогенній формі депресії і найвищою у реемігрантів з органічною депресією, причому в реемігрантів показники залишалися на найвищому рівні серед усіх груп, що підтверджує залежність психоемоційного стану від впливу об'єктивних соціально-психологічних фракторів. У цієї категорії виявлено найбільшу депресивну предиспозицію з підвищеною чутливістю до стресу, ознаками дезадаптації, що викристалізовуються в астено-депресивний, депресивно-тривожний та депресивно-іпохондричний стани. Для реемігрантів притаманним виявилося поєднання шкал песимістичності та індивідуалістичності, що віддзеркалювало такі особистісні риси, як занижена самооцінка, занурення у власні переживання, втрата комунікативних якостей, що є логічним внаслідок втрати можливостей задовольнити свої життєві потреби.

У реемігрантів 3 ендогенними порушеннями особистісні трансорормації виявилися глибшими порівняно з психогенними депресіями і свідчили про схильність до самоприниження та самокритичності, розвиненим почуттям провини, внутрішньою напруженістю, фріксацією на неприємних відчуттях та переживаннях, що створювало стійкий депресивний фон.

Потрібно зауважити, що різниця між показниками у кожній з порівнювальних груп профрілю песимістичності була значущою, достовірною також виявилася різниця між неемігрантами та емігрантами $(p<0,01)$.

Профрілі неемігрантів та емігрантів найчастіше характеризувалися поєднанням шкал песимістичності та тривожності, що виявляє тривожнопомислові особистості зі схильністю до фробій, панічних нападів, неспокою $з$ приводу будь-яких життєвих ситуацій, невпевненості у своїх силах, схильністю до нав'язливостей.

Привертає увагу той фракт, що показники за шкалою тривожності (рис. 2) в емігрантів у всіх групах спостереження були найвищими і достовірно відрізнялися від неемігрантів. Встановлені високі рівні тривожності у емігрантів за умов психогенного впливу узгоджуються з виявленими нами значними проявами тривоги у цій групі за шкалами HARS. Водночас деталізація особливостей патохарактерологічних змін емігрантів показала наявність типових характерологічних змін у цій групі, a саме: високої сенситивності, зниженого порогу толерантності до стресу, схильності до сумнівів, 
емпатійності, підвищеної відповідальності. Високі показники за шкалою тривожності у реемігрантів підтверджують вищеописані особливості психічного стану цієї групи. Водночас він $є$ значуще меншим, ніж в емігрантів $(p<0,05)$.

Певні закономірності виявлені при спостереженні другої за вираженістю шкали - тривожності у пацієнтів з ендогенними порушеннями. Показники даного симптому відрізняються меншою мі- рою між собою, хоча у всіх трьох групах середні значення показників $€$ вищими, аніж у попередньої групи. Значущу різницю спостерігали між емігрантами (у них показник виявився найвищим) та неемігрантами $(p<0,01)$. Тоді як у реемігрантів зменшення не досягло статистично значущого рівня ( $>>0,05)$.

Цікавим виявився той фракт, що тривога в пацієнтів з органічними розладами досягла найвищого

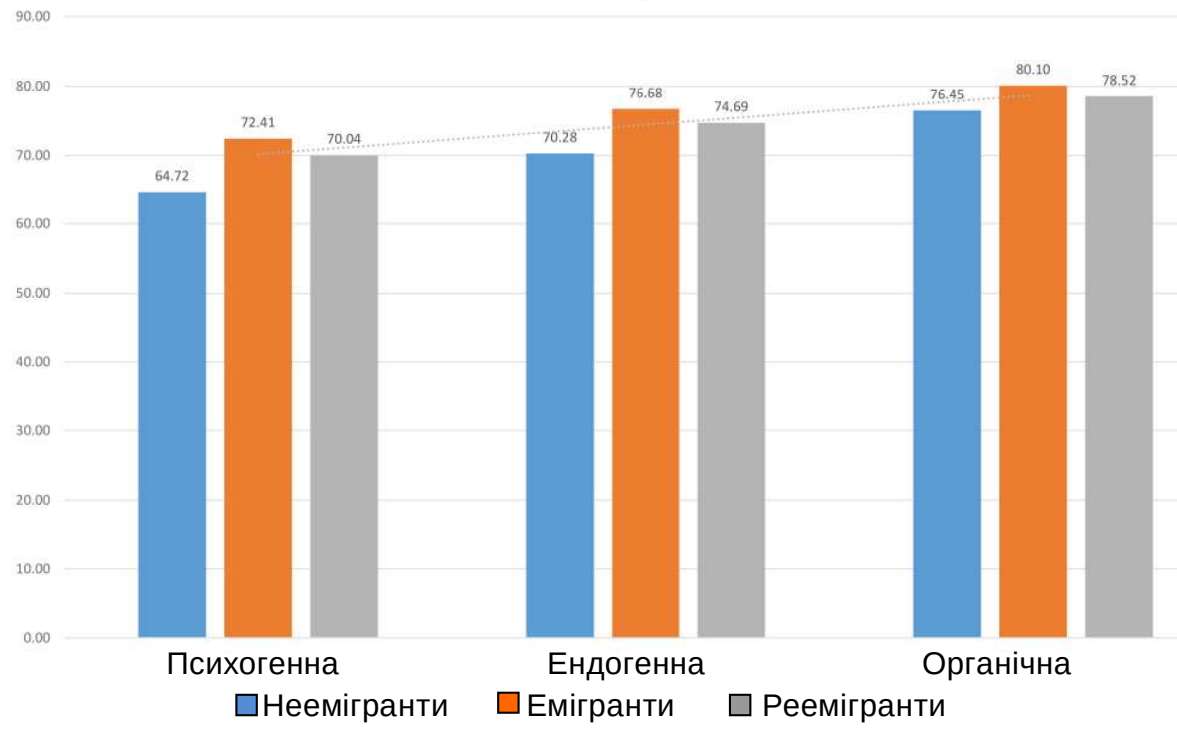

Рuc. 2. Профіль тривоги.

рівня у всіх групах спостереження, хоча загальна тенденція розподілу показника збереглася: найбільш виражена в емігрантів, менша в реемігрантів і найнижча в неемігрантів, причому різниця залишалася статистично значущою. У реемігрантів цієї групи патохарактерологічні трансорормації досягли максимального рівня. Таким чином, депресивні розлади на органічному підґрунті зумовлюють вираження депресивно-тривожних проявів, схильність до тривожного реагування, уникання соціальних контактів та соматизацію симптомів із домінуванням тривожності.

Спроба вивчення гендерних особливостей реагування на зміну життєдіяльності призвела до отримання таких даних за шкалою мужностіжіночності у досліджених хворих (рис. 3). Як у чоловіків, так і в жінок найбільш високі рівні за цією шкалою виявлено у емігрантів $(54,11 \pm 4,46)$ бала та $(56,24 \pm 14,66)$ бала відповідно, значно нижчі -у неемігрантів $(48,42 \pm 1,89)$ бала та $(42,21 \pm 13,40)$ бала, а найнижчі - у реемігрантів $(43,51 \pm 2,86)$ бала та $(39,02 \pm 4,88)$ бала. Значущі розбіжності виявлено при порівнянні всіх груп. Цікавим $€$ той фракт, що чоловіки, хворі на депресивні розлади, не демонстрували принципових відмінностей у плані маскулінізації або фремінізації. Натомість при обстеженні жінок за цією шкалою виявлено високі показники у емігрантів, що відображають риси мужності, незалежності, самостійності у прийнятті рішень. Статистично меншими були показники у неемігрантів та реемігрантів, що свідчили про прагнення бути опікуваною, знайти опору в чоловікові, м'якість, сентиментальність, прихильність до сімейних інтересів, сором'язливість.

Таким чином, виявлені тенденції свідчать про суттєво більшу статево-рольову диференціацію емігрантів та реемігрантів - жінок порівняно $з$ чоловіками.

Особливості показників за шкалою мужностіжіночності у пацієнтів з ендогенною депресією акцентувалися на змінах у чоловіків, втраті їх самостійності, здатності приймати рішення та виклики долі, сенситивності та пасивності. Особливо стосувалися такі характеристики реемігрантів $((45,68 \pm 2,7)$ бала), меншою мірою - неемігрантів $((47,37 \pm 2,4)$ бала) та емігрантів $((49,91 \pm 3,6)$ бала). Розбіжності значущі при порівнянні груп неемігрантів і реемігрантів, емігрантів та реемігрантів $(p<0,05)$. Схожими були результати обстеження пацієнтів з органічною патологією, де основні тенденції повторювали вектор напрямку змін при ендогенних розладах.

\section{Висновки}

В усіх обстежених хворих виявлено різний ступінь афективних розладів, причому найбільший рівень депресії встановлено у пацієнтів 3 ендогенними розладами, що супроводжувався, відповідно, високою тривогою. Лідерами серед цих порушень виявилися емігранти. Порівнюючи групи емігрантів та реемігрантів, встановле- 


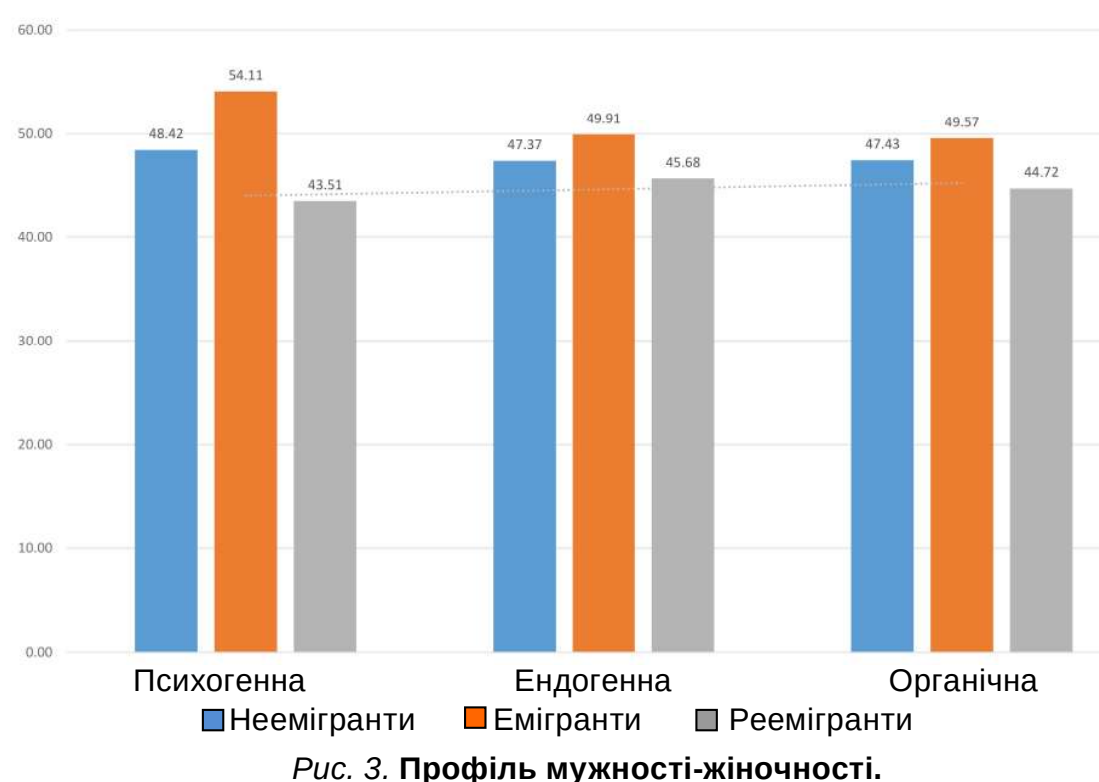

но, що за умов ендогенних розладів емігранти характеризувалися вищими показниками соматизації та тривожності, а реемігранти - міжособистісної сенситивності та депресії. В той же час суїцидальна активність була характерною для реемігрантів усіх типів депресії. Найбільш високими спостерігали показники шкали песимістичності, що відображає основну тенденцію до зниженого настрою, у поєднанні з високим профілем за шкалою тривожності.
Перспективи подальших досліджень. Дослідження особливостей структури синдрому афективних порушень у емігрантів та реемігрантів має важливе медичне та соціальне значення. Ступінь психосоціальної адаптації та інтеграції емігрантів у країнах-реципієнтах значною мірою визначається індивідуально-типологічними рисами та рівнем адаптивних ресурсів особистості.

\section{Список літератури}

1. Блинова О. Є. Психологічне здоров'я мігрантів: результати емпіричного дослідження / О. Є. Блинова // Освіта регіону. - 2013. - № 2. - С. 244-248.

2. Венгер О. П. Особливості депресивних розладів у емігрантів та реемігрантів / О. П. Венгер // Медична психологія. 2015. - T. 10, № 2. - С. 27-30.

3. Ковальчук А. Психологічні наслідки трудової міграції для мігрантів та їхніх сімей [Електронний ресурс] / А. Ковальчук. - Режим доступу : http://ena.Ip.edu.ua:8080/bitstream/ntb/16855/1/26-210-216.pdf.

4. Некоторые особенности психологической адаптации мигрантов [Электронный ресурс] / В. Б. Колянова, В. П. Боряк, Н. В. Барнаш, Л. В. Михайленко // ЦМИ. - Режим доступа : http://migrocenter.ru/conferenceskavkaz-m_ kavkaz030.

5. Слюсаревський М. М. Психологія міграції : навч. посіб. / М. М. Слюсаревський, О. Є. Блинова ; Національна академія педагогічних наук України, Інститут соціальної та політичної психології. - Кіровоград : Імекс, 2013. - 242 с. 6. Хаустова О. О. Психосоціальна реабілітація: проблеми і шляхи вирішення / О. О. Хаустова // Архів психіатрії. 2015. - T. 21, № 2. - С. 36-42.

7. Юрценюк О. С. Особливості лікування психотичних психічних розладів у жінок - трудових мігрантів / О. С. Юрценюк // Молодий вчений. - 2014. - № 1 (04). - С. 190-192.

\section{References}

1. Blynova, O.Ye. (2013). Psyholohichne zdorovia mihrantiv: rezultaty empirychnoho doslidzhennia [Psychological health of migrants: the results of empirical research]. Osvita rehionu - Education of the Region, 2, 244-248 [in Ukrainian]. 2. Venher, O.P. (2015). Osoblyvosti depresivnykh rozladiv mihrantiv ta reemihrantiv [Peculiarities of depressive disorders in emigrants and re-emigrants]. Medychna Psyholohiia - Medical Psychology, 10 (2), 27-30 [in Ukrainian].

3. Kovalchuk, A. Psyholohichni naslidky trudovoi mihratsii dlia mhrantiv ta yikhnikh simei [Psychological consequences of labor migration for migrants and their families]. Retrieved from: http://ena.lp.edu.ua:8080/bitstream/ntb/16855/1/26-210216.pdf [in Ukrainian].

4. Kolyanov, V.B., Boryak, V.P., Barnash, N.V., \& Mihaylenko, L.V. Nekotorye osobennosti psikhologicheskoy adaptatsii migrantov [Some features of the psychological adaptation of migrants]. TSMI. Retrieved from: http://migrocenter.ru/ conferences-kavkaz-m_kavkaz030 [in Russian].

5. Slyusarevskyy, M.M., \& Blynova, O.Ye. (2013). Psyhologiya migratsii [Psychology of migration]. National Academy of Pedagogical Sciences of Ukraine, Institute of Social and Political Psychology. Kirovohrad: Imeks [in Russian]. 
6. Haustova, O.O. (2015). Psykhotsotsialna reabilitatsiia: problemy i shliakhy vyrishennia [Psychosocial rehabilitation: problems and solutions]. Arkhiv psykhiatrii - Archive of Psychiatry, 21 (2), 36-42 [in Ukrainian].

7. Yurtseniuk, O.S. (2014). Osoblyvosti likuvannia psykhotychnykh psykhichnykh rozladiv u zhinok - trudovykh mihrantiv [Features of treatment of psychotic mental disorders in women - labor migrants]. Molodyi vchenyi - Young Scientist, 1 (04), 190-192. Retrieved from: http://nbuv.gov.ua/UJRN/molv_2014_1(04)_44 [in Ukrainian].

\section{POSSIBILITIES OF ADAPTATION RESOURCES OF EMIGRANTS AND RE-EMIGRANTS ACCORDING TO THEIR PERSONAL FEATURES \\ O. P. Venger, L. M. Sas, Yu. I. Mysula, O. Ye. Smashna, V. S.Bilous, O. O. Liuta, T. P. Husieva, M. Ye. Koval, V. O. Pastushak \\ I. Horbachevsky Ternopil National Medical University, Ternopil, Ukraine}

Purpose: to study the possibilities of adaptation resources of emigrants and re-emigrants according to their personal characteristics.

Materials and Methods. We used the clinical-psychopathological method, psychometric (M. Hamilton Depression Scale (HDRS), M. Hamilton Anxiety Scale (HARS), Starshenbaum GV Suicide Risk Assessment Scale) and psychodiagnostic methods.

Results. The study of the structure of the depressive syndrome of different etiological direction (endogenous, exogenous and organic) in emigrants and re-emigrants, as well as the features of affective disorders that occur during migration, is not only a key task today, but also an attempt to solve social problems. Implementation of these tasks will help to find a differentiated approach to treatment and find rational ways to provide care.

The obtained data supplement the available information about the change in the psychological state of migrants: the features of the symptoms of the depressive spectrum, the patterns of their occurrence and severity, possibility of suicidal activity depending on the origin of the disorder. It was found that objective sociopsychological conditions create the basis for the emergence of patterns of violations, which, along with individual personality traits leads to the development of neurotic variants of maladaptation and decompensation of the individual in the direction of increased inhibitory reactions.

Conclusions. On the basis of a comprehensive study, the patterns of affective disorders have been established, which can serve as a basis for the development and testing of new treatment approaches and methods of rehabilitation of migrants.

KEY WORDS: adaptive abilities; emigrants and re-emigrants; affective disorders; personality traits.

Рукопис надійшов до редакції 02.07.2020 p.

\section{Відомості про авторів:}

Венгер Олена Петрівна - доктор медичних наук, профресор, завідувач кафедри психіатрії, наркології та медичної психології Тернопільського національного медичного університету імені І. Я. Горбачевського МОЗ України; тел.: +38(0352) 43-57-71.

Сас Леся Михайлівна - кандидат медичних наук, доцент кафедри психіатрії, наркології та медичної психології Тернопільського національного медичного університету імені І. Я. Горбачевського МОЗ України; тел.: +38(0352) 43-57-71.

Мисула Юрій Ігорович - кандидат медичних наук, доцент кафедри психіатрії, наркології та медичної психології Тернопільського національного медичного університету імені І. Я. Горбачевського МОЗ України; тел.: +38(0352) 43-57-71.

Смашна Олена Євгенівна - кандидат медичних наук, доцент кафредри психіатрії, наркології та медичної психології Тернопільського національного медичного університету імені І. Я. Горбачевського МОЗ України; тел.: +38(0352) 43-57-71.

Білоус Володимир Сергійович - кандидат медичних наук, асистент кафедри психіатрії, наркології та медичної психології Тернопільського національного медичного університету імені І. Я. Горбачевського МОЗ України; тел.: +38(0352) 43-57-71.

Люта Ольга Олександрівна - кандидат медичних наук, асистент кафедри психіатрії, наркології та медичної психології Тернопільського національного медичного університету імені І. Я. Горбачевського МОЗ України; тел.: +38(0352) 43-57-71.

Гусєва Тетяна Павлівна - кандидат психологічних наук, асистент кафредри психіатрії, наркології та медичної психології Тернопільського національного медичного університету імені І. Я. Горбачевського МОЗ України; тел.: +38(0352) 43-57-71.

Коваль Маріанна Євгенівна - асистент кафедри психіатрії, наркології та медичної психології Тернопільського національного медичного університету імені І. Я. Горбачевського МОЗ України; тел.: +38(0352) 43-57-71.

Пастушак Василь Орестович - асистент кафедри психіатрії, наркології та медичної психології Тернопільського національного медичного університету імені І. Я. Горбачевського МОЗ України; тел.: +38(0352) 43-57-71. 